\begin{tabular}{|c|c|c|c|c|}
\hline Submission & Review Process & Revised & Accepted & Published \\
\hline $18-12-2021$ & $20-12$ s/d 19-01-2021 & $22-01-2021$ & $30-01-2021$ & $31-01-2021$ \\
\hline
\end{tabular}

Ampera: A Research Journal on Politics and Islamic Civilization, Vol. 2 No.1, Januari 2021 (81-94)

Published by: Politik Islam UIN Raden Fatah Palembang

\title{
Perebutan Pengaruh Kheji dan Centeng dalam Pencalonan Kades Terusan MUBA Sumsel
}

\section{Dede Purwira}

Fakultas Adab dan Humaniora Universitas Islam Negeri Raden Fatah Palembang

Email: dedepurwira96@gmail.com

\begin{abstract}
Kheji and Centeng are the two local elite figures who are in Terusan Village, Sanga Desa Subdistrict, who have great influence in Terusan Village so that these two figures become references for political figures in increasing their electability. Kheji is a figure known as one of the respected religious figures because of his personality and the nature of courtesy that is applied in his daily life. Meanwhile, centeng is a figure who is respected by the community because of his arrogant nature and physical strength such as immunity and other knowledge. Based on the description above, the main problem in this research is how about the struggle for influence between kheji and centeng in increasing the electability of a candidate for village head in Terusan Village, Sanga District. Village of Musi Banyuasin Regency

The purpose of this study is to explain how these two figures can become influential people in Terusan Village, Sanga District, Musi Banyuasin Regency. The usefulness of this research is expected to be able to provide knowledge for the Terusan village community how the influence exerted by these two local elite figures. Based on the research conducted in Terusan Village, it can be concluded that these two figures have a strategic influence and position in Terusan village so that these two figures are able to change the behavior and choices of others with the influence they have.
\end{abstract}

Keywords: cleric, local elite, kheji and centeng

\begin{abstract}
ABSTRAK
Kheji dan centeng adalah kedua tokoh elit lokal yang berada di Desa Terusan Kecamatan Sanga Desa yang memiliki pengaruh yang besar di desa Terusan sehingga kedua tokoh ini menjadi acuan tokoh politik dalam meningkatkan elektabilitasnya. Kheji adalah sosok
\end{abstract}


yang dikenal sebagai salah satu tokoh agama yang terpandang karena keperibadian dan sifat sopan santun yang diterapkan dalam kesehari-hariannya. Sedangkan centeng adalah tokoh yang di segani masyarakat karena sifat arogan dan memiliki kekuatan fisik seperti kekebalan dan ilmu lainnya.Berdasarkan uraian diatas permasalahan pokok dalam penelitian ini adalah bagaimana dengan perebutan pengaruh antara kheji dan centeng dalam meningkatkan elektabilitas dari suatu calon kades di Desa Terusan Kecamatan Sanga Desa Kabupaten Musi Banyuasin

Tujuan dari penelitian ini adalah untuk menjelaskan bagaimana kedua tokoh ini bisa menjadi orang yang berpengaruh di Desa Terusan Kecamatan Sanga Desa Kabupaten Musi Banyuasin. Kegunaan penelitian ini diharapkan nantinya agar dapat memberikan pengetahuan bagi masyarakat desa Terusan bagaimana pengaruh yang di berikan oleh kedua tokoh elit lokal ini. Berdasarkan penelitian yang peneliti lakukan di Desa Terusan dapat diambil kesimpulan bahwa kedua tokoh ini memiliki pengaruh dan posisi yang startegis di desa Terusan sehingga kedua tokoh ini mampu merubah perilaku dan pilihan orang lain dengan pengaruh yang dimiliki.

Keywords: kiai, elit lokal, kheji dan centeng

\section{PENDAHULUAN}

Penelitian ini akan mengkaji tentang dua tokoh elit lokal di Kecamatan Sanga Desa Kabupaten Musi Banyuasin kedua tokoh tersebut adalah kheji dan centeng?, keduanya merupakan tokoh yang mempunyai posisi atau kedudukan penting dalam masyarakat di Kecamatan Sanga Desa. Yang mana kedudukan itu untuk mencapai sesuatu kekuasaan tertentu, sendangkan kekuasaan yang hakiki hanya dimiliki Allah swt dan ialah yang memberi kekuasaan dan mengambil juga kekuasaan. (Ali Imran, 26)

Kheji adalah tokoh agama atau juga bisa di sebut orang yang paham ilmu khususnya dibidang agama Islam, dan centeng adalah orang yang kuat dalam fisik dan juga merupakan orang yang menjaga keamanan di wilayah Kecamatan Sanga Desa.

Pertama ialah kheji keberadan sosok kheji di Kecamatan Sanga Desa sudah ada seiring dengan masuknya Islam ke Indonesia hingga saat ini pun tetap memiliki peran yang besar di wilayah Kecamatan Sanga Desa tersebut. Peran kheji secara garis besar merupakan sosok yang bisa menjawab setiap masalah keagamaan yang senantiasa timbul di hadapi masyarakat di Kecamatan Sanga Desa, selain itu kheji dikatakan pula sebagai penjaga moral dan bantengnya masyarakat Kecamatan Sanga Desa. kheji bertanggung jawab menyelesaikan persoaalan agama. kheji bersipat Independen (berdiri sendiri) dan moderat (tidak memihak) tanpa mengikuti aliran-aliran tertentu dalam membimbing umat. Pengaruh kheji yang melewati batas-batas geografis pedesaan khususnya di Kecamatan Sanga Desa Kabupaten Musi Banyuasin berkat legitimasi masyarakat untuk memimpin upacara-upacara keagamaan, adat dan menginterpretasikan doktrin-doktri agama di daerah Khususnya di Kecamatan Sanga Desa.

Selain itu seorang kheji dipandang memiliki kekuatan-kekuatan spritual karena kedekatanya dengan Sang Pencipta dari pandangan ini lah bahwa masyarakat di Kecamatan Sanga Desa percaya bahwa kheji ini memiliki karoma, oleh nya masyarakat di Kecamatan Sanga Desa ketika, anaknya, suaminya, dan siapa saja yang sakit ketika ilmu kedokteran tidak dapat lagi menangani gejalah sebuah penyakit yang aneh dan 
jarang ditemui, kheji itu lah menjadi tempat kedua untuk berobat. Kheji tidak hanya dikenal memiliki kekuatan spritual saja penampilan kheji yang khas dengan seperti bertutur kata yang lembut, berperilaku yang sopan, berpakaian rapi dan sederhana, serta membawa tasbih berdzikir kepada Allah, merupakan simbol-simbol kesolehan. Tidak hanya itu kheji ini juga memiliki harta benda yang lebih dari cukup oleh karna itu perilaku dan ucapan seorang kheji menjadi panduan masyarakat di Kecamatan Sanga Desa dalam kehidupan sehari-hari.

Kedua ialah centeng golongan ini juga menembus batas-batas hirarki pedesaan di Kecamatan Sanga Desa. Centeng sebagai orang yang memiliki keunggulan dalam fisik dan kekuaatan-kekuatan memanifulasi kekuatan supernatural, seperti penggunan jimat, sehingga ia disegani oleh masyarakat yang ada di Kecamatan Sanga Desa. Jimat yang memberikan harapan dan memenuhi kebutuhan praktis para centeng yang salah satunya adalah kekebalan tubuh dari benda- benda tajam, dan senjata-senjata yang di gunakan oleh centeng ini seperti kris dan golok sebagai simbol mereka sebagai seorang centeng yang ada di Kecamatan Sanga Desa. sama halnya dengan kheji yang memiliki jaringan centeng ini juga memiliki organisasi mereka yang kerap di sebut oleh masyarakat Kecamatan Sanga Desa Kabupaten Musi Banyuasin dengan sebutan PK (Pengawas Keamanan).

Fenomena centeng di Indonesia khususnya di Desa Terusan kecamatan Sanga Desa Kabupaten Musi Banyuasin mulai berkembang pada saat ekonomi semakin sulit dan anggka pengangguran semakin tinggi. Kelompok masyarakat Kecamatan Sanga Desa yang kebinggungan dengan ekonomi dan penggangguran semakin tinggi mereka mencari cara untuk mendapatkan penghasilan biasanya melalui pemerasan dalam bentuk penyediaan jasa yang sebenarnya tidak dibutuhkan. Dan centeng ini sangat identik dengan kriminal dan kekerasan karena memang centeng ini tidak lepas dari kedua hal tersebut.

Dari fenomena itu lah centeng yang berada di Kecamatan Sanga Desa memanfaatkan yang kaya akan sumber daya alam mereka seperti banyak berdiri perusahaan-perusahaan kelapa sawit, dan kaya juga akan minyak bumi di tanah kelahiran mereka dengan kelebihan yang mereka miliki seperti ilmu silat dan ilmu kekebalan, centeng ini memiliki peluang yang besar untuk mendapatkan pekerjaan dan ekonomi yang baik, dari sini lah centeng ini sudah mulai terlihat kedudukannya dalam wilayah Kabupaten Musi Banyuasin Kecamatan Sanga Desa centeng ini awalnya menguasai wilayah yang berada di kecamatan Sanga Desa Khususnya.

Hingga mereka ini menjadi salah satu kelompok kepercayaan dari perusahanperusahaan yang ada di wilayah Kecamatan Sanga Desa seperti PT WPG, PT IBP, PT MBE, dan banyak lagi PT-PT yang berdiri di daerah Kecamatan Sanga Desa, dari menjadi kelompok kepercayaan ini lah mereka memanfaatkan situasi yang berpihak kepada mereka yang mana mereka ini juga bisa merekrut orang untuk bisa bekerja di PT-PT tersebut.

Tidak hanya memanfaatkan perusahan -perusahaan yang ada diwilayah tersebut akan tetapi anggota centeng ini yang memiliki modal yang cukup mereka juga bembuat tempat penyulingan minyak dan bor minyak bumi setelah berhasil dan menghasil kan minnyak yang banyak "meluing" centeng ini juga merekrut pekerja untuk bekerja di pertambangan mereka yang telah menghasilkan. Dan tidak hanya perusahan-perusahan dan pertambangan centeng ini juga memiliki kebun-kebun pribadi seperti kebun karet, kebun 
kelapa sawit, kebun buah-buahan, sawah dan lain sebagainya yang mana kebun kebun itu dirawat dan bagi hasil oleh orang yang di rekrutnya untuk menjadi pekerjanya.

Dari fenomena-fenomena kedua peran tokoh elit lokal tersebut antara kheji dan centeng ini yang selalu memainkan peran sesuai dengan apa kemampuannya sehingga masyarakat di Kecamatan Sanga Desa ini memiliki hutang budi baik itu dari kheji yang sosoknya dikenal dengan kesolehannya dan memiliki karomah sehingga masyarakat itu jika kata kheji pilih Dia maka masyarakat pun memilih atas kehendak kheji tersebut karena masyarakat percaya atas saran yang di berikan oleh kheji yang ada di Kecamatan Sanga Desa.

Dan juga dari golongan kedua yaitu centeng sama hal nya juga dengan kheji bahwa masyarakat di Kecamatan Sanga Desa ini juga memiliki hutang budi dengan centeng ini selain centeng ini memberikan rasa keamanan di lingkungan masyarakat setempat centeng ini juga memberikan suatu jasa nya kepada masyarakat yakni bahwa masyarakat di berikan pekerjaan melalui kekuasaan yang dia miliki dan harta yang bisa dikatakan berlimpah, dari hal tersebutlah bahwa masyarakat Kecamatan Sanga Desa juga menuruti kehendak centeng itu juga jika centeng itu memerlukan bantuan masyarakat yang pernah ia bantu.

\section{TINJAUAN LITERATUR}

Kajian tentang elit lokal sejatinya sudah banyak dilakukan peneliti sebelumnya antara lain, yang disusun oleh Thiami, Dkk yang berjudul Kharisma Kiai dan Jawara di Banten yang menjelaskan bahwa kiai dan Jawara. bahwa adanya kedudukan, peran dan jaringan membuat kiai dan jawara menciptakan kultur tersendiri yang agak berbeda dengan kultur dominan masyarakat Banten, sehingga kiai dan jawara tidak hanya menggambarkan suatu sosok tetapi juga telah menjadi kelompok yang memiliki nilai, norma dan pandangan hidup yang khas. Itulah subkultur kiai dan jawara. (Khudaeri, 2003

Karenanya, gelar kiai merupakan suatu tanda kehormatan dalam kedudukan sosial, bukan suatu gelar akademis yang diperoleh dalam pendidikan formal. Sementara itu, jawara adalah seorang atau sekelompok yang memiliki kekuatan fisik dalam bersilat dan mempunyai ilmu-ilmu kesaktian (kadigjayaan), seperti kekebalan tubuh dari senjata tajam, bisa memukul dari jarak jauh dan sebagainya, sehingga bagi orang lain dapat membangkitkan rasa hormat dan takut, serta kagum dan benci. Karena kelebihannya itu, ia dapat menjadi seorang tokoh yang kharismatik, terutama pada saat-saat kehidupan sosial mengalarni krisis. Banten sangat menentukan. Tentunya, demikian ini mengalami peningkatan peranan yang signifikan dibandingkan dengan peranan masa-masa lalu dalam sejarah kehidupan masyarakat Banten, sehingga dapat menentukan masa depan kesejarahan masyarakatnya

Dalam penelitian Asep Muslim, Dkk. Dinamika Peran Sosial Politik ulama dan Jawara di Pandeglang Banten peran sosial-politik jawara. Sebagai sebuah konstruksi sosial, peran sosial-politik kyiai dan jawara saat ini merupakan realitas sosial yang sudah teruji kematangannya dalam membentuk tatanan sosial masyarakat Pandeglang. Kenyataan adanya dominasi jawara dalam arena politik praktis di Pandeglang sejatinya dimaknai sebagai sebuah proses sosial normal dalam menuju tatanan sosial yang khas Pandeglang. Adanya wacana politik dinasti dalam konteks dominasi jawara di Banten umumnya dan Pandeglang khususnya sejatinya dimaknai sebagai sebuah proses sosial 
yang normal pula. Dalam hal ini dimaknai sebagai sebuah pencarian jati diri demokrasi lokal di Pandeglang. (Muslim, 2015)

Namun hal ini dapat menjadi persoalan sosial ketika dominasi politik jawara membawa dampak buruk terhadap konstelasi sosial politik Pandeglang misalnya adanya korupsi birokrasi, pelayanan publik yang buruk dan marginalisasi pihak-pihak tertentu sebagaimana yang terjadi pada kasus korupsi mantan Gubernur Banten, Ratu Atut Chosiyah. Dalam kondisi ini, diperlukan kekuatan negara untuk mereduksi dampak buruk tersebut. Oleh karenanya, meskipun dominasi jawara di Pandeglang sebagai sebuah realitas sosial, kelembagaan negara sangat dibutuhkan untuk mengendalikan dominasi yang menjurus kepada kekuasaan absolut. Hal ini perlu dilakukan, karena kekuasaan absolut relatif mendorong terjadinya perilaku KKN (Korupsi, Kolusi dan Nepotisme)

Dalam jurnal Muhammad Hudaeri jawara di Banten peran, kedudukan dan jaringannya. Jawara dalam percakapan sehari-hari masyarakat Banten merujuk kepada seseorang atau kelompok yang memiliki kekuatan fisik dalam bersilat dan mempunyai ilmu-ilmu kesaktian, seperti kekebalan tubuh dari senjata tajam, bisa memukul dari jarak jauh dan sebagainya, sehingga membangkitkan perasaan orang lain penuh dengan pertentangan: hormat dan takut, rasa kagum dan benci. Berkat kelebihannya itu, ia bisa muncul menjadi tokoh yang kharismatik, terutama pada saat-saat kehidupan sosial mengalami krisis.

Sedangkan menurut hemat peneliti, menariknya penelitian ini dan yang membedakan penelitian ini dengan yang sebelumnya bahwa dari literatur review yang peneliti ambil sebagai referensi bahwa jawara dan kiai ini memiliki hubungan antara satu sama lain dan memiliki visi satu tujuan antara jawara dan kiai dan memiliki jaringan yang dikategorikan besar dan luas. Sendangkan penelitian ini peneliti melihat bahwa dimana kheji dan centeng ini tidak terikat satu sama lain dan mereka memiliki tujuan berbeda dalam suatu perkara dan ada disebabkan adanya fenomena-fenomena yang muncul di Kecamatan Sanga Desa seperti yang telah dijelaskan di latar belakang.

\section{METODE PENELITIAN}

Penelitian yang digunakan yaitu penelitian kualitatif deskriptif. Penelitian kualitatif deskriptif adalah berupa penelitian dengan metode atau pendekatan studi kasus (case study). Sendangkan Taylor Moleong menyatakan bahwa metodelogi kualitatif merupakan prosedur penelitian yang menghasilkan data deskriftif berupa kata kata tertulis atau lisan dari orang-orang dan pearilaku yang dapat diamati. Pendekatan ini diarahkan pada latar dan induvidu yang teliti secara holisif (utuh). Dalam hal ini tidak boleh mengisolasikan individu atau kelompok kedalam variabel atau hipotesis, tetapi perlu memandangnya sebagai bagian dari suatu keutuhan. Penelitian kualitatif dalam penelitian ini bertujuan memberikan gambaran secara deskriftif tentang data yang didapatkan dari lokasi penelitian dalam bentuk kata-kata tertulis atau lisan dari informan yang diteliti.

Penelitian ini memusatkan diri secara intensif pada suatu objek tertentu yang terkait rumusan masalah. Dan data studi kasus dapat diambil dan dianalisa dari semua pihak yang bersangkutan, dengan kata lain dalam studi ini dikumpulkan dari berbagai sumber-sumber.. Penelitian ini akan melihat bagaimana posisi kheji dan centeng di Kecamatan sanga Desa dan seberapa besar pengaruh kheji dan centeng ini di Kecamatan Sanga Desa dalam bidang sosial, ekonomi dan politik. 


\section{HASIL DAN PEMBAHASAN}

Dalam masyarakat desa Terusan untuk menjadi calon seorang kades masyarakat juga memiliki kriteria tersendiri dalam memilih kepala desa nya karena mereka tidak ingin dipimpin oleh pemimpin yang salah, karena sudah ada buktinya pada pimpinan kepala desa sebelumnya dipimpin oleh kepalah desa yang salah desa mereka tidak maju dan tertinggal oleh sebab itu masyarakat desa Terusan tidak ingin mengulang kesalahan yang sama seperti sebelumnya. Jika mereka salah dalam memilih pemimpin maka akan hancur desa tersebut dalam jangka waktu yang panjang yaitu 6 tahun, hal ini disampaikan juga oleh bapak Dola sebagai tokoh masyarakat pada waktu diwawancarai.

Pemilihan kepala desa merupakan salah satu sarana legal untuk melakukan pergantian kekuasaan di tingkat desa. Disamping bertujuan untuk melakukan pergantian kekuasaan, pilkades juga bermanfaat sebagai ruang evaluasi atas kepemimpinan priode sebelumnya oleh masyarakat apakah kedepannya nanti masih layak memimpin desa tersebut atau tidak. Pilkades dalam tataran praktisnya adalah proses pemilihan orangorang untuk mengisi jabatan-jabatan politik tertentu.

Tidak dapat dipungkiri bahwa sekarang orang berlomba-lomba untuk memperebutkan jabatan sebagai kepala desa karenanya ada suntikan dana yang cukup besar untuk tiap-tiap desa, namun tidak jarang juga banyak kepala desa yang terjerumus menyelewengkan dana desa tersebut sehingga mereka terjebloskan dalam penjara, namun untuk mejadi kepala desa ini harus memiliki kriteria sebagaimana yang telah dicantumkan dalam Pemendagri no 65 tahun 2017 pasal 21 calon kepala desa wajib memenuhi persyaratan:

Pada tingkat undang-undang, UU No. 39 tahun 1999 tentang Hak Asasi Manusia Pasal 43 yang menentukan bahwa : "Seiap warga negara berhak untuk dipilih dan memilih dalam pemilihan umum berdasarkan persamaan hak melalui pemungutan suara yang langsung, umum, rahasia, bebas, jujur, dan adil sesuai dengan ketentuan peraturan perundang-undangan.

Hak pilih juga tercantum dalam International Covenant on Civil and Political Right (ICCPR) yang telah di ratifikasi Indonesia dengan UU No.12 tahun 2005 tentang Pengesahan Internasional Covenant on Civil and Political Right (Kovenan Internasional Tentang Hak-Hak Sipil Dan Politik). Pasal 25 ICCPR menentukan bahwa "setiap warga negara juga harus mempunyai hak dan kebebasan, tanpa pembedaan apapun sebagaimana di maksud dalam pasal 2 dan tanpa pembatasaan yang tidak beralasan:

a) Ikut dalam melaksanakan urusan pemerintahaan, baik secara langsung maupun melalui wakil-wakil yang dipilih secara bebas;

b) Memilih dan dipilih pada pemilihan umum berkala yang jujur, dan dengan hak pilih yang universal dan sama, serta dilakukan melalui pemungutan suara secara rahasia untuk menjamin kebebasan dalam menyatakan kemauan dari para pemilih;

c) Memperoleh akses pada pelayanan umum di negaranya atas dasar persamaan.

Pilkades serentak secara umum relatif berlangsung dengan demokratis, aman dan damai, bahkan pilkades serentak di Indonesia sebagai sebuah eksperimen demokrasi yang demikian mengagumkan yang patut untuk dicontoh oleh negara-negara lainnya, namun dari keberhasilan pelaksanaan pilkades serentak ini terbesit hal yang menganggu dan merisaukan sehingga menjadi masalah baru untuk demokrasi yakni rendahnya partisipasi pemilih namun karena rendanya tingkat partisipasi pemilih pihak penyelenggara 
melakukan sosialisasi, akan tetapi tidak hanya adanaya dari penyelegara pilkades saja yang menarik partisipasi pemilih namun ada dukungan dari pihak lain, yakni peran elit lokal. Keikut sertaan elit lokal mengajak masyarakat untuk turut andil dalam menyukseskan pilkades serentak ini.

Keberadaan elit lokal di Desa Terusan Ini menjadi salah satu pemicu atau sosok yang sanagat pentig dalam masyarakat karena mereka ini dapat diposisikan sebagai opinion leader. Dalam suatu tatanan masyarakat desa Terusan opinion sendiri mencakup elit politik, kheji, centeng, dan ketua adat. Hal tersebut terjadi karena elit lokal ini memiliki kedekatan emosional dengan masyarakat interpersonal, sehingga bentuk komunikasi yang dilakuakan oleh para elit lokal tersebut mendapatkan perhatian yang khusus oleh masyarakat.

Dalam wawancara yang dilakukan oleh peneliti pada pihak yang bersangkutan di Desa Terusan tentang bagaimana pandangan terhadap kedua tokoh antara kheji dan centeng, untuk wawancara yang dilakukan pada tahap ini merupakan pertanyaann umum tentang kedua tokoh yakni antara kheji dan centeng. Kepada bapak Dolla selaku tokoh masyarakat Desa Terusan mengatakan: Kheji sebagai salah satu tokoh atau pemuka agama yang ada di desa terusan, namun kheji ini dari seorang yang berkiprah dalam bidang agama dia salah satu tokoh atau sosok yang di percaya oleh masyarakat desa terusan namun disisi lain kheji ini dimanfaatkan oleh elit-elit politik untuk meningkatkan dan meraup perolehan suara dalam pilkades di Desa Terusan Kecamatan Sanga Desa Kabupaten Musi Banyuasin. Hal ini dilakukan dengan cara memodifikasi peran dan kedudukan kheji yang pada dasarnya sebagai orang dipercaya untuk menyelesaikan persoalan agama menjadi bagian dari tim sukses calon kades.

Hal serupa juga di sampaikan oleh Rodal Tha Sebagai salah satu tokoh agama bahwa kheji ini adalah sosok yang terpandang yang dihormati kedudukannya di masyarakat desa terusan karena ilmu tentang agama yang ia miliki untuk mengajak, menasehati, serta menuntun masyarakat untuk kearah yang lebih baik.

Adapun juga dengan centeng elit lokal satu ini sangat berpengaruh di dalam masyarakat tergolong ke dalam elit lokal lokal yang tidak memerintah namun memiliki pengaruh dan peran besar di dalam masyarakatnya yakni dalam suatu tatanan Desa Terusan. Pengaruh centeng ini sanagat luar biasa sehingga ia jadi salah satu rebutan para tokoh elit politik dalam mencari elit lokal khususnya di Desa Terusan dalam pelaksanaan Pilkades. Dan tidak pernah diduga bahwa kedua tokoh elit lokal ini saling rebutan untuk menarik simpati warga dalam menaikan elektabilitas dan suara dari masing-masing calon kades dukungan mereka agar memperoleh hasil yang tidak mengecewakan dikemudian harinya.

Kedua tokoh elit lokal di desa Terusan ini pengaruhnya berdampak besar bagi keberlangsungan demokrasi di Indonesia dan ini juga bisa menjadi percontohan bagi daerah-daerah yang ada di Indonesia khususnya di tingkat perdesaan yang minim akan partisipasi politiknya, karena kedua tokoh ini meningkatkan partisipasi politik lewat jaringan mereka dan sosialisasi mereka terhadap masyarakat desa Terusan Kecamatan Sanga Desa Kabupaten Musi Banyuasin. Bentuk partisipasi politik ini di bagi menjadi beberapa bagian yakni :

1. Kegiatan pemilihan yaitu kegiatan pemberian suara dalam pemilihan umum, menjadi tim sukses, mencari dukungan bagi calon. Atau tindakan lain yang berusaha mempengaruhi hasil pemilu dan lain sebagainya 
2. Lobby yaitu upaya perorangan atau kelompok menghubungi orang-orang yang di anggap penting seperti pimpinan politik dengan maksud mempengaruhi keputusan mereka tentang suatu isu.

3. Kegiatan organisasi atau kelompok yaitu partisipasi induvidu ke dalam organisasi baik selaku anggota maupun pimpinanya, guna mempengaruhi pengambilan keputusan.

4. Contacting yaitu upaaya induvidu atau kelompok dalam membangun jaringan guna memperbanyak masa atau suara

5. Tindakan kekerasan yaitu tindakan induvidu atau kelompok seperti dengan cara menciptakan kerugian fisik manusia atau harta benda termasuk di sini adalah huruhara.

Tidak menuntup kemungkinan berhasilnya meningkatkan partisipasi politik tentunya ada juga dampak negatif yang akan ditimbulkan kedepannya. Kelima partisipasi politik menurut Huntinton dan Joan Nelson telah menjadi bentuk klasik dalam studi partisipasi politik.

Tentunya dari apa yang dilakukan melalui pergerakan kedua tokoh elit lokal yang ada di Desa Terusan Kecamatan Sanga Desa Kabupaten Musi Banyuasin tidak biasa olehnya kheji dan centeng ini membuat dampak yang fositif bagi keberlangsungan demokrasi di Indonesia dan ini juga satu nilai plus dan patut untuk di contohkan oleh daerah-daerah lainya di seluruh penjuruh tanah air bahkan juga untuk negara-negara berkembang di luar sana yang menganut sistem demokrasi”.

\section{Pengaruh Kheji Dan Centeng Di Kecamatan Sanga Desa Dalam Bidang Sosial, Ekonomi Dan Politik}

Dalam studi tentang partisipasi politik di negara berkembang pengaruh adalah bagaimana cara seseorang bisa merubah pikiran dan perilaku agar bisa mengikuti keinginan seseorang yang bisa mengendalikan suatu keadan di suatu daerah karena posisi yang dimiliki baik itu harta, jabatan dan lain sebagainya. Menurut Hugiono dan Poerwatana "pengaruh merupakan dorongan atau bujukan dan bersifat membentuk atau merupakan suatu efek", sedangkan menurut Badudu dan zain "pengaruh adalah daya yang menyebabkan sesuatu terjadi, sesuatu yang dapat membentuk atau mengubah sesuatu yang lain dan untuk tunduk atau mengikuti kehendak karena kuasa dan kekuasaan orang lain. Sedangkan Lois Gottschalk mendefinisikan pengaruh sebagai suatu efek yang tegar dan membentuk terhadap pikiran dan perilaku orang lain baik sendiri-sendiri maupun perkolektif.

Pengaruh juga merupakan suatu dampak yang di lakukan oleh seseorang ataupun lebih sehingga menimbulkan reaksi berupa tindakan atau keadaan dari suatu perlakuan akibat dorongan untuk mengubah atau membentuk suatu keadaan kearah yang lebih baik dari yang sebelumnya. Maka pengaruh yang dimaksud dalam penelitian ini adalah pengaruh yang dilakukan kedua tokoh elit lokal yakni kheji dan centeng yang ada di daerah desa Terusan Kecamatan Sanga Desa, seperti yang dilakukan dalam meningkatkan partisipasi pemilih dalam Pilkades.

Sikap masyarakat dalam berintaksi atau hidup besosial dalam keadaan sehari-hari dalam suatu tatanan masyarakat desa Terusan Kecamatan Sanga Desa Kabupaten Musi Banyuasin keadaan sosial ini menjadi salah satu tolak ukur suatu desa bisa dikatakan 
apakah suatu desa tersebut sudah maju apa belum. Dalam studinya tentang sejarah, Hugiono 1987 Pada dasarnya istilah "sosial" memiliki beberapa pengertian beberapa pengertian yang berbeda yang dianggap sebagai konsep dan merujuk antara lain pada: sikap, orientasi, atau perilaku yang mempertimbangkan kepentingan, niat, atau kebutuhan orang lain (berbeda dengan perilaku anti sosial) telah berperan dalam mendefinisikan ide atau prisip. Kata "sosial" berasal dari bahasa latin "socil" yang artinya sekutu. Istilah tersebut sangat erat hubungannya dengan suatu kehidupan manusia dalam masyarakat, misalanya sifat yang mengarah pada rasa empati terhadap orang lain yang disebut dengan jiwa sosial.

Proses yang menggunakan kekuasaan untuk menegakkan peraturan-peraturan dan keputusan-keputusan yang sah berlaku di tengah masyarakat. berikut ilustrasi gambaran sosok seorang tokoh kheji dan centeng. Adapun penilaian kerakter kheji dan centeng tersebut ditinjau dari beberapa aspek yakni:

Untuk melihat pengukuran peneliti melihat beberapa aspek dalam kepribadian atara kheji dan centeng yaitu sebagai berikut: dari aspek perilaku dapat dilihat bahwa kheji ini adalah orang yang lemah lembut tidak kasar, sabar, dibanding dengan centeng yang memiliki perilaku yang arogan, gegabah, dan tegas, namun walaupun ada perbedaan antara kheji dan centeng ini tidak mengurangi tingkat kepercayaan masyarakat desa Terusan. Sedangkan dari aspek sosial kheji dan centeng ini tentunya memiliki perbedaan karena mereka ini memiliki kharisma masing-masing, kheji adalah sosok yang dihormati di tengah masyarakat, sendangkan centeng ini adalah sosok yang lebih di segani karena ia adalah orang yang selalu tegas dalam ucapan dan perbuatannya oleh karena masyarakat segan akan sosok centeng ini.

Jika sosok seorang kheji ini di hormati Tentunya dengan centeng yang sosoknya di segani dalam masyarakat desa Terusan, dari kata di hormati ini tentunya sosok kheji ini sopan santun terhadap orang lain olehnya kheji dimasyarakat desa Terusan ia selalu dipuji dan di sanjung akan perbuatannya. Namun berbeda dengan centeng ini ia adalah sosok yang disegani dalam masyarakat karena ia adalah sosok yang tegas dalam berucap dan bertindak oleh nya sosok beliau ini di segani.

Dari aspek spritual memang terlihat jelas tokoh agama tentunya memang dikenal sosok orang yang paham agama, jadi orang tidak heran lagi dengan apa yang dilakukan dan yang diadakan oleh kheji ini dalam hal yang berbasis agama. Sedangkan centeng memang orang yang dikatan jauh dari agama tentunya memang ia kurang perduli terhadap kegiatan yang berbasis agama.

Dari aspek ekonomi kheji memang tidak terlalu kaya namun dibilang mampu, kheji ini adalah sosok yang darmawan yang selalu memperhatikan tetangga dan slalu bersedekah kepada orang yang tidak mampu. Centeng ini soal ekonomi memang tidak diragukan lagi karena ia adalah orang yang mempunyai pengaruh yang besar dalam perusahan perusahan yang ada di batas wilayah desa Terusan tentunya beliau juga orang yang royal terhadap masyarakat jika berkumpul bersama masyarakat ataupun teman atau tetangganya. Kekayaan bukanlah segalanya jika tidak bermanfaat bagi orang lain sifat kedarmawanan kheji ini patut ditiru untuk berpolitik karena kedua sosok ini secara tidak sengaja menanam kebaikan tentunya orang lain merasa mempunya hutangbudi atas apa yang diberikan ke masyarakat.

Dari deskripsi ditas, dapat disebutkan bahwa kheji adalah seorang tokoh panutan masyarakat desa terusan,karena kheji ini ia fokus mengarahkan dan membimbing 
masyarakat agar tidak salah dalam memilih pemimpin namun disisi lain kheji ini mengrahkan masyarakat agar memilih pemimpin yang disaran kan oleh kheji ini. Jika pemimpin yang disarankan kheji ini terpilih kheji ini tidak menginginkan apa-apa.

Berbeda dengan centeng ini ia terlalu ambisi terhadap kekuasaan, karena apabila calon kades yang di dukung menang maka centeng ini ada saja permintaan seperti memegang kekuasaan wilayah desa Terusaan "yang dimaksud memegang wilayah terusan ialah ketika ada sebuah perusahaan yang ingin membuka lahan maka centeng ini meminta untuk menjadi kepala bagian keamanan di sebuah perusahaan seperti yang sudah sudah di tahun 2015 ada perusahaan yang berdiri di wilayah desa Terusan maka perusahaan itu wilayah nya centeng itu atas rekomendasi dari kepala desa terpilih tersebut.

Inilah bentuk yang dikatakan dengan politik balas budi atau juga politik etis. Ketika pemilihan kepala desa centeng membantu calon kades sebagai tim sukses yang ia dukung untuk meraup masa atau mencari suara agar calon yang ia dukung itu menang namun ketika calon kades tersebut terpilih maka centeng tersebut pun meminta bantuan agar dipermudah urusanya seperti jika centeng ini ada masalah diperushaan maka kepalah desa tersebut membantu dikemudian hari.

\section{Posisi Kheji dan Centeng Di Desa Terusan Kecamatan Sanga Desa Kabupaten Musi Banyuasin}

Dalam tatanan masyarakat khususnya masyarakat desa Terusan Kecamatan Sanga Desa Kabupaten Musi Banyuasin, sumber ekonomi dan kekuasaan masih sangat memiliki peran yang penting, sehingga para pengusaha dan penguasa yang ada di desa Terusan yang memiliki sumber ekonomi dan lapangan pekerjaan mampu mempengaruhi perilaku atau sikap orang lain yang memiliki status yang lebih rendah .

Hal ini juga disampaikan oleh bapak andriyadi selaku masyarakat Desa Terusan mengatakan bahwa elit lokal ini selain memiliki peran penting mereka juga memiliki posisi yang stategis walaupun mereka bukan pejabat pemerintahan tetapi mereka ini bisa mengendali dan mempengaruhi masyarakat karena mereka ini dihormati dan disegani dalam masyarakat desa Terusan.

Keterbatasan terhadap sumber ekonomi inilah masyarakat desa Terusan Kecamatan Sanga Desa yang menjadikan ketimpanagan dan kesenjangan antara pihak yang memiliki dan menguasai sumber ekonomi, lapangan pekerjaan dengan mereka pihak yang tidak memiliki akses sumber ekonomi, dengan keaadan ini lah kedua tokoh elit lokal ini memanfaatkan keadaan atau posisi mereka untuk mempengaruhi masyarakat desa Terusan agar bisa memperoleh suara yang banyak serta elektabilitas dari suatu calon kades tersebut itu naik. Hal ini lah juga yang menyebabkan adanya tergantungan antara tokoh elit lokal yang mempunyai sumber akses ekonomi dan lapangan pekerjaan dengan masyarakat desa Terusan yang sangat membutuhkan kedua duanya untuk melanjutkan serta keberlangsungan hidup mereka.

Keterbatasan terhadap sumber ekonomi dan lapangan pekerjaan ini lah yang menyebabkan adanya ketimpangan dan kesenjangan antara tokoh elit lokal dan masyarakat desa Terusan Kecamatan Sanga Desa Kabupaten Musi Banyuasin, seperti warga desa Terusan yang ingin membuka usaha, baik itu untuk membuka bengkel, jualan sayur kedalam PT dan usaha dagang lainnya akan tetapi mereka mau membuka usaha 
berhalangan dengan modal oleh sebab itu lah tokoh elit lokal ini sebagai pemilik sumber ekonomi bisa menjamin modal untuk mereka yang membutuhkan modal usaha tersebut

Begitu juga dengan mereka masyarakat desa Terusan baik untuk mereka sendiri maupun anak-anak mereka yang membutuhkan pekerjaan tokoh elit lokal ini bisa menyediakan karena centeng ini selain memiliki sumber ekonomi ia juga dekat dengan pengusaha dan pemerintahan oleh sebabnya centeng ini bisa memasukan warganya untuk bekerja di perusahaan atau intansi pemerintahan. Sebagai masyarakat yang tidak memiliki akses ekonomi dan lapanggan pekerjaan masyarakat juga memiliki hutang budi atas apa yang telah di beri tokoh elit lokal ini kepada mereka. Menurut James Scout, patron merupakan satu pola hubungan yang berbentuk kebergantungan antara satu sama lain. Hal ini dimana menurut Scot, patron merupakan induvidu yang berada dalam kedudukan untuk membantu klien-klien. Pada tahap selanjutnya, klien pula akan membalas dengan menawarkan bantuan atau perkhidmatan yang diperlukan oleh patron.

Istilah centeng dalam percakapan sehari-hari masyarakat di Kecamatan Sanga Desa khususnya desa Terusan sendiri memiliki dua sudut pandang yang pertama ialah menunjukan referensi identifikasi seseorang adalah gelar bagi orang-orang yang memiliki kekuatan fisik dalam bersilat dan mempuyai ilmu-ilmu kesaaktian, seperti kekebalan tubuh dari senjata tajam. Sudut pandang yang kedua centeng ini sering juga dikatakan dengan istilah yang negatif, centeng ialah salah satu sifat orang yang merendahkan derajat yang biasnya untuk digunakan oleh orang-orang yang berperilaku sombong, kurang taat terhadap perintah agama islam atau melakukan sesuatu dengan cara yang tidak baik.

Dalam wawancara pribadi dengan ibu desi triyana mengatakan: "Tidak hanya fakor ekonomi saja yang bisa mempengaruhi masyarakat desa Terusan karena kedekatan emosional dengan masyarakat dan pemerintah juga menjadi pemicu kedua tokoh elit lokal ini memiliki posisi yang baik di desa tersebut, dengan kedekatan dengan masyarakat, masyarakat tidak segan atau menerima dengan baik jika pada saat kedua tokoh elit lokal ini memberi masukan kepada masyarakat begitu juga dengan pejabat pemerintahan desa dan juga elit elit politik". Yang penting di dalam desa Terusan faktor spritual juga masih sangat penting dan berperan di tengah-tengah masyarakat, seperti di acara hajatan dan kematian warga yang inggin melakukan hajatan dan juga yang mendapat musibah otomatis mereka perlu tokoh agama untuk memandu acara tersebut agar berjalan dengan lancar karena untuk melakukan hal tersebut butuh orang yang memang benar-benar ahlinya dalam mengurus hal yang seperti itu.

Tidak hanya ini kheji dalam masyarakat desa Terusan sangat-sangat dibutuhkan untuk menjadi suri tauladan mereka agar masyarakat desa Terusan nantinya tidak jauh dan melenceng dari pedoman yang diajarkan dalam al-Quran. Kheji adalah tokoh agama yang mempunyai ilmu lebih dalam bidang agama, kheji ialah sosok yang dipercaya sebagai pembawa misi, dalam artian bahwa allah menitipkan amanah di pundaknya, kapan dan dimanapun berada. Amanah harus dijaga baik-baik dan disampaikan kepada yang berhak menerimanya, karena amana itu akan diminta pertanggung jawabannya, sebagai seoarang pembawa misi seorang tokoh agama yang selalu berdiri kokoh dengan keperibadiannya yang utuh dengan ilmu yang luas, dengan langgkah yang pasti dengan penuh kebijaksanaan.

Berdasarkan dengan Teori Elit yang di kemukakan oleh Vilfaredo Pareto sekelompok orang yang memegang kekuasaan yang terkekmuka dalam suatu tatanan 
masyarakat kheji dan centeng merupakan orang-orang pilihan atau terpilih kheji dan centeng ini mempunyai posisi tertentu yang memberikan kekuasaan dalam menentukan dalam mengambil keputusan.Selama proses penelitian dilakukan peneliti juga melihat kekeluargaan yang terjalin dalam ruang lingkup kedua tokoh elite lokal..

\section{KESIMPULAN}

Dari uraian pada pembahasan diatas penulis dapat menyimpulkan beberapa faktor temuan mengenai perebutan pengaruh elektabilitas calon kades oleh kedua tokoh antara kheji dan centeng sebagai berikut : Pertama, Pengaruh dari kedua tokoh elit lokal dari bidang sosial bahwa kedua tokoh elit lokal ini mudah masuk melakukan pendekatan secara emosional terhadap pemerintah dan juga dekat dengan masyarakat, dibidang ekonomi bahwa kedua tokoh ini mampu menguasai sumber perekonomian yang ada di Desa Terusan dan memeliki harta kekayaan yang dibilang mampu di daerah tersebut untuk membantu orang lain. Politik kedua tokoh dilihat dari kedekatan secara emosional dan memiliki harta kekayaan sehingga mampu membantu masyarakaat yang membutuhkan bantuan dari hal tersebutlah timbul yang dinamakan politik balas budi antara kedua tokoh elit lokal dan masyarakat sehingga ini juga membentuk sistem pattron-klien dimana baik antara kedua tokoh elit lokal dengan pemerintah maupun masyarakat, mereka sama-sama menguntungkan satu sama lain.

Kedua, posisi kheji dan centeng di kecamatan Sanga Desa. Kheji adalah sosok yang sangat dihormati karna kesolehan dan tutur kata yang bijak serta sopan santun dengan sesama dari hal yang kecil yang selalu di tanamkan dalam bermasyarakat kheji adalah sosok yang berpengaruh dan memiliki posisi, kedudukan di desa Terusan yakni memiliki kedekatan secara emosional dengan masyarakat yakni dengan memodifikasi kedekatannya lewat kesehariannya sebagai ulama pangung yang selalu memberi nasehat, serta arah yang lebih baik kepada masyarakat desa Terusan. Lewat keperibadiannya lah kheji dikenal dan dihormati, lewat pengaruh kheji ini ia bisa mencari masa dalam menaikan suara dari elit politik yang menurutnya bagus dan layak untuk didukung sebagai calon kades. Namun tidak sembarangan orang yang bisa mendapatkan dukungan dari kheji karena kheji ini memiliki kriteria untuk maju sebagai kandidat.

Sedangkan dengan centeng sosok yang dikenal dengan keperibadian yang arogan namun centeng ini juga salah satu tokoh yang berpengaruh dan memiliki kedudukan yang hampir sama dengan kheji namun ada sedikit yang berbeda dari centeng ini dalam melakukan ataupun mencari masa untuk mendukung calon kades yang ia dukung. Dengan sosok dia dimasyarakat yang disegani dan ditakuti oleh masyarakat. Dengan prilaku dan sifat yang arogan yang dimiliki centeng bisa mempengaruh dan merubah pilihan orang lain untuk menuruti keinginan dan kemauan dari centeng. Centeng dalam memilih pemimpin tidak ada kriteria seperti kheji.

Keperibadian yang disegani masyarakat bahkan di kalangan pengusaha, centeng mampu mengendalikan perilaku orang lain karena jasa yang ia tanam kepada masyarakat yakni dengan memberikan bantuan baik itu jasa maupun material dari ini juga, seperti ketika masyarakat membutuhkan bantuan centeng ini juga ringan tangan dalam membantu masyarakat yang membutuhkan bantuan.

Kedua tokoh ini sama-sama memiliki pengaruh akan tetapi dari pengaruh yang diberikan kepada masyarakat tentunya kedua tokoh elit lokal ini memiliki kelebihan 
mereka masing-masing, kelebihan kheji dan centeng ini sama-sama bisa masuk kedalam masyarakat sehingga mampu membentuk kedekatan secara emosional dengan masyarakat desa Terusan Kecamatan Sanga Desa Kabupaten Musi Banyuasin.

Ketika penelitian ini di relasikan dengan teori elit lokal yang dikemukakan oleh Vilfredo Pareto mengatakan pada awalnya dipakai untuk membedakan minoritasminoritas yang dianggkat untuk melayani suatu kolektivias dengan cara yang bernilai sosial yang pada gelirannya bertanggung jawab terhadap realisasi tujuan-tujuan sosial yang utama dan untuk kelanjutan tata sosial dengan mencangkup penyertaan pada suatu proses yang berlangsung. Maka saya menyimpulkan penelitian ini sangat relevan dengan teori yang dikemukakan oleh Vilfredo Pareto. 


\section{DAFTAR PUSTAKA}

Asep Muslim dinamika peran sosial politik Kheji dan jawara di pandeglang banten, Vol. 31, No.2 Desember 2015, https://ejournal.unisba.ac.id/index.php/mimbar/article/view/1555

Fadli, Muhammad, dkk. 2018. keterlibatan elite lokal dalam peningkatan partisipasi politik pada pemilihan kepala daerah. 6 (2) : 12-14.

Gottschalk, Lois 2000. Mengerti sejarah, Depok : Yayasan Penerbit Universitas Indonesia.

Hudaeri. Muhammad 2003 ,"jawara di Banten peran, kedudukan dan jaringannya",dalam jurnal Alqalam. 2 (97) : (74-75).

Indriyanti Azhar Firdausi, “Jawara Dalam Budaya Banten”, dalam Jurnal Lontar, 4 (3) : 29-31

Lorenza, D. (2020). Elit Lokal Berbasis Pesantren Dalam Kontestasi Politik Di Kecamatan Banyuasin III Studi Pada Pencalonan Buya H.M Husni Thamrin Madani Tahun 2018. Ampera: A Research Journal on Politics and Islamic Civilization, 1(3), 184-198. https://doi.org/https://doi.org/10.19109/ampera.v1i3.7431

Mikail, Kiki. "PEMILU DAN PARTAI POLITIK DI INDONESIA: Menanti Kebangkitan Partai Politik Islam Di Tahun 2019”. Tamaddun: Jurnal Kebudayaan dan Sastra Islam 15, no. 1 (April 7, 2016): 107-148. Accessed February 7, 2021. http://jurnal.radenfatah.ac.id/index.php/tamaddun/article/view/444.

MUI Pusat, Himpunan Fatwa MUI Sejak Tahun 1975, Jakarta: Erlangga.

Nasution, M.A., Penelitian Naturalistik Kualitatif, (Bandung,: Tarsito, 2003) hlm. 56.

Rusli Lutan. Pengukuran dan Evaluasi Pembelajaran (Jakarta: Dapertemen Pendidikan Nasional 2000)

Samuel P. Huntington dan Joan Nelson , Partisipasi Politik di Negara Berkembang, (Jakarta: Rineka Cipta, 1990) Hal. 9-10

Sari, N. (2020). Kiyai dan Politik: Analisis Peran kiyai dalam PIlkada OKI 2018 Kecamatan SP Padang. Ampera: A Research Journal on Politics and Islamic Civilization, 1(3), 208-225. https://doi.org/https://doi.org/10.19109/ampera.v1i3.7428

Sartono Kartodjiro, 1998 pemberontakan petani Banten 1998, pustaka jaya, Jakarta.

Scout ,JC 1972, Petron-dient politics and political change in southeasAsia American political Science Review 66 (1) :91-113

Singgarimbun, Misri dan Sofian Efendi, 1993, Metodologi penelitian survey, Jakarta:LP3ES.

Soerjono Soekanto. Sosiologi Suatu Pengantar, (Jakarta: PT Raja Grafindo Persada 2003) hlm.35

Sugiono, Metodelogi Penelitian Kualitatif dan Kuantitatif, Bandung : Penerbitan Alfabeta, 2017, hal. 3

Thihami 1992, “Kiai dan Preman di Banten” Tesis Master, Universitas Indonesia, Jakarta. 